\title{
UJI KINERJA MESIN DIESEL GENERATOR MENGGUNAKAN BAHAN BAKAR MODE SISTEM DUAL FUEL SOLAR DAN SYNGAS HASIL GASIFIKASI DARI TONGKOL JAGUNG
}

\author{
Romi Djafar), Agus Sussanto Ginting ${ }^{2)}$ \\ ${ }^{1,2}$ Program Studi Mesin dan Peralatan Pertanian, Politeknik Gorontalo \\ Email: romidjafar@poligon.ac.id ${ }^{1)}$
}

\begin{abstract}
ABSTRAK
Saat ini ketersediaan bahan bakar fosil semakin langka dan harganya semakin meningkat sehingga dibutuhkan sumber energi alternatif yang sifatnya dapat diperbaharui. Sumber energi alternatif seperti biomasa dapat dikonversi menjadi syngas melalui proses gasifikasi untuk berbagai keperluan misalnya Internal combustion engine (ICE).

Penelitian ini mengaplikasikan syngas reaktor downdraft dari bahan bakar tongkol jagung untuk mesin diesel generator set. Tujuan penelitian adalah mengetahui performa reaktor gasifikasi, performa mesin diesel, dan mengetahui jumlah bahan bakar solar yang tergantikan dengan adanya penambahan syngas. Untuk mendapatkan hasil penelitian maka produser gas dilewatkan melalui saluran inlet gas analizer yang beroperasi secara real time kemudian keluar menuju intake manifold mesin diesel. Adapun variasi pembebanan yang dilakukan adalah 200-2000 Watt pada interval 200 Watt dengan kecepatan konstan mesin diesel sebesar 1500 rpm.

Hasil penelitian menunjukkan bahwa komponen syngas yang dihasilkan masing-masing kosentrasi adalah $\mathrm{O}_{2}(10,2-26,7 \%), \mathrm{H}_{2}(7,9-13,6 \%), \mathrm{CH}_{4}(6,6-19,5 \%), \mathrm{CO}(9,2-16,5 \%), \mathrm{CO}_{2}(6,3-14,5 \%)$.dan $\mathrm{N}_{2}(59.8-$ $43.3 \%)$. Efisiensi gas dingin gasifikasi diperoleh sebesar 35.5\% dengan konsumsi bahan bakar sebesar 1.22 $\mathrm{kg} / \mathrm{jam} . \mathrm{kW}$. Sedangkan jumlah bahan bakar solar yang tergantikan dengan adanya penambahan syngas yaitu sebesar $47.4 \%$. Secara menyeluruh efisiensi total sistem diperoleh sebesar $10.8 \%$.
\end{abstract}

Kata kunci: Reaktor, Dual Fuel, Syngas. Efisiensi

\section{ABSTRACT}

Currently, fossil fuels is scarce and it's price is increased, so energy renewable sources alternative are needed. Actually energy sources such as biomass can be converted to syngas through a gasification process for various purposes, eg Internal Combustion Engine (ICE).

In this research, downdraft reactor syngas application from corncob fuel for diesel engine generator set. This study aimed to determine performance of gasification reactor, diesel engine, and determine amount of diesel fuel that was replaced by syngas addition. To get results of the research, gas producer is passed through inlet gas analizer channel which operates in real time then exits to the diesel engine intake manifold directly. The generator load is varying between 200-2000 Watt intervals 200 Watt at with a constant speed at $1500 \mathrm{rpm}$.

The results showed that syngas components produced concentrations are O2 (10.2-26.7\%), H2 (7.9$13.6 \%), \mathrm{CH} 4(6.6-19.5 \%), \mathrm{CO}(9.2-16.5 \%), \mathrm{CO} 2(6.3-14.5 \%)$ and $\mathrm{N} 2(59.8-43.3 \%)$. Cold gasification efficiency at $35.5 \%$ with fuel consumption of $1.22 \mathrm{~kg} /$ hour. $\mathrm{kW}$ respectively. While a amount of diesel fuel replaced by syngas addition is $47.4 \%$ with overall system efficiency is $10.8 \%$.

Keywords: Reactor, Dual Fuel, Syngas. Efficiency

\section{PENDAHULUAN}

Di Indonesia umumnya kebutuhan energi listrik di perkotaan disuplai oleh PLN yang berasal dari Pembangkit Listrik dengan bahan bakar fosil seperti batubara dan bahan bakar gas. Penggunaan bahan bakar fosil secara terus menerus telah memberikan berbagai dampak saat ini, seperti ketersediaannya semakin berkurang, harga dipasaran global terus meningkat serta polusi udara yang berasal dari debu dan asap pembakaran bahan bakar fosil tersebut. Salah satu upaya yang dapat dilakukan untuk meminimalisir persoalan tersebut adalah teknologi gasifikasi biomasa sebagai alternatif yang cocok untuk diaplikasikan menggerakkan generator listrik.

Raman et al.,2018 melakukan desain pengembangan dan analisis performa sistem gasifikasi dual chamber untuk aplikasi pembangkit listrik yang bertujuan untuk mencari solusi berbagai hambatan mengenai kemurnian gas serta proses teknologinya melalui metode dry cleaning dan water cooling. Hasil penelitian menunjukkan bahwa 
jumlah tar yang diijinkan untuk mesin pembakaran mesin dalam adalah sebesar $100 \mathrm{mgNm}^{3}$ dengan efisiensi gas dingin sebesar 89\%. Adapun rekomendasi penelitian kedepannya yaitu aplikasi produser gas untuk listrik skala yang lebih besar.

Metode menghilangkan tar dan berbagai hal lainnya Jena et al., 2018 menggunakan media filter untuk aplikasi internal combustion dengan mengatur parameter rasio ekivalen gasifikasi. Hasil penelitian menunjukkan bahwa untuk dapat menjalankan mesin maka kandungan tar sebesar $150 \mathrm{mgNm}^{3}$. Berdasarkan hasil analisis disimpulkan bahwa metode menjernihkan produser gas dapat dilakukan dengan berbagai metode namun tidak dapat merubah komposisi dari syngas tersebut.

Rizkal dan Sudarmanta.,2016 melakukan eksperimen dengan proses pemasukan aliran syngas yang dihasilkan downdraft municipal solid waste (MSW) ke dalam saluran mesin diesel generator set secara langsung menggunakan sistem mixer. Tujuan penelitian untuk melihat seberapa besar jumlah bahan bakar yang digunakan saat menggunakan sistem dual fuel. Akan tetapi kajian tersebut tidak meneliti mekanisme dual fuel dengan penyimpanan terlebih dahulu pada tabung bertekanan.

Homdoung et al.,2015 melakukan investigasi mesin skala kecil hasil modifikasi menggunakan bahan bakar syngas. Modifikasi dilakukan terhadap suatu mesin diesel ke dalam model pengapian sistem injeksi sehingga bahan bakar menjadi $100 \%$ syngas. Mesin hasil modifikasi tersebut terhubung dengan dynamometer untuk mengetahui performa mesin berupa daya torsi, efisiensi dan konsumsi bahan bakar. Untuk mendapatkan hasil penelitian maka digunakan variasi putaran mesin. Namun hasil kajian tidak meneliti efek perubahan beban listrik.

Aplikasi untuk mesin pembakaran dalam selanjutnya yaitu studi eksperimen downdraft gasifier Ram et al., 2012 dengan dua laluan suplai udara pembakaran yang menghasilkan gas mampu bakar digunakan pada mesin diesel sistem dual fuel untuk menghasilkan energi listrik.

Penelitian lain dilakukan oleh Chaves et al., 2015 tentang small-scale power generation analysis downdraft gasifier coupled to engine generator set. Tujuan utama penelitian adalah memb erikan konstribusi terhadap energi listrik dengan metode tekno analisis mengenai pembangkit skala kecil dari bahan bakar limbah kayu untuk menghasilkan syngas yang dihubungkan sebuah unit generator set. Hasil kajian menyimpulkan bahwa efisiensi rata-rata downdraft gasifier sebesar 60$70 \%$ dengan efisiensi total sistem terendah antara 4.5-17\%.

Berdasarkan literatur sebelumnya maka tujuan penelitian ini adalah aplikasi syngas downdraft gasifier menggunakan bahan bakar tongkol jagung yang diintegrasikan langsung ke mesin diesel menjadi sistem dual fuel solar-syngas.
Tujuan utama penelitian adalah mengetahui seberapa besar penghematan bahan bakar solar ketika adanya penambahan syngas dalam mesin diesel.

\subsection{Model downdraft Gasifier}

Penelitian ini dilakukan menggunakan reaktor gasifikasi biomassa tipe downdraft dengan dua laluan udara yang dilakukan oleh Djafar dan Darise.,2018. Adapun spesifikasi reaktor gasifikasi memiliki ukuran tinggi $115 \mathrm{~cm}$ dan diameter sebesar $50 \mathrm{~cm}$. Sedangkan diameter throat sebesar $15 \mathrm{~cm}$. Ketebalan bahan yang digunakan adalah $2 \mathrm{~mm}$ dari material galvanis steel. Kemudian Untuk mereduksi panas yang keluar dari dalam reaktor dipasang isolasi dari bahan glasswall. Sedangkan indikator suhu dipasang termokopel tipe $\mathrm{K}$ sebanyak 5 titik dipasang sepanjang ketinggian reaktor $\mathrm{T} 1$ zona drying, T2, T3, zona pirolisis, T4 zona oksidasi, dan T5 zona reduksi. Skema alat uji pada Penelitian ini ditunjukkan pada Gambar 1 sebagai berikut.

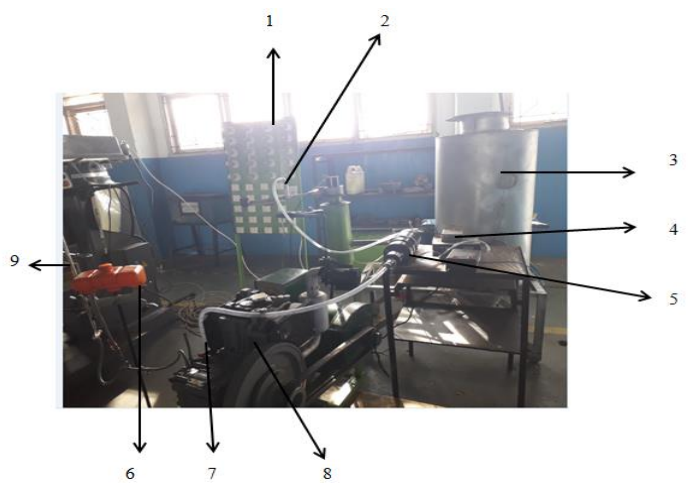

Gambar 1. Integrasi Reaktor Downdraft dengan Generator Set

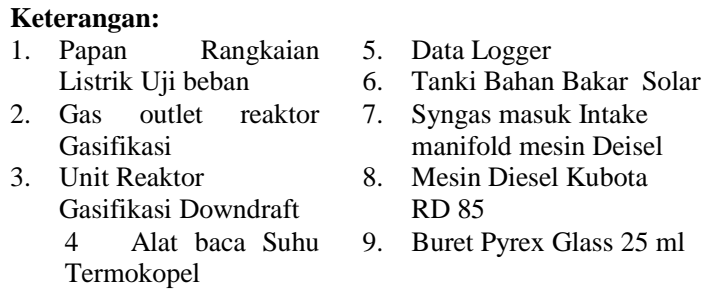

\subsection{Diesel Generator Set}

Reaktor downdraft pada Gambar 1 akan memproduksi gas mampu bakar kemudian kopel secara langsung pada mesin diesel yang akan memutar generator listrik, selanjutnya putaran mekanik dikonversi menjadi energi listrik menyalakan lampu pada papan kontrol percobaan. Adapun spesifikasi generator adalah generator (Yasuka) dengan daya $5 \mathrm{~kW}$ pada putaran $1500 \mathrm{rpm}$.

\subsection{Langkah-Langkah Pengujian}

Proses pengujian dapat berlangsung dengan baik maka terlebih dilakukan beberapa tahapan sebagai berikut: 
1. Persiapan biomassa berupa tongkol jagung sebagai bahan bakar berdasarkan pengukuran menggunakan moisture meter sebesar $13 \%$.

2. Pemeriksaan kondisi reaktor mulai dari kebersihannya, pengecekan bagian kelengkapan hingga reaktor dipastikan dapat berfungsi dengan baik.

3. Masukkan bahan bakar tongkol jagung sampai batas nozzle, selanjutnya dilakukan penyalaan awal dibantu dengan kertas yang dicelupkan pada solar untuk mempermudah start-up.

4. Kemudian atur kecepatan udara yang disuplai oleh blower dengan mengatur katup (full open) yang terpasang dipipa/nozzle di luar reaktor sesuai ukuran bukaan katup yang dibutuhkan.

5. Lakukan start up penyalaan api dalam reaktor

6. Apabila api sudah menyala dengan temperatur diatas $300^{\circ} \mathrm{C}$ selanjutnya reaktor di isi penuh $(5 \mathrm{~kg} /$ batch $)$ kemudian hopper inlet ditutup rapat.

7. Ketika kondisi sudah steadi maka selanjutnya mesin diesel dihidupkan kondisi standar.

8. Lakukan pengaturan kecepatan mesin sebesar $1500 \mathrm{rpm}$

9. Lakukan integrasi syngas dengan saluran intake manyfold mesin diesel

10. Lakukan variasi pembebanan dengan interval 200 watt.

\section{Kajian Pustaka}

Gasifikasi secara bahasa dapat diartikan sebagai pembuatan gas. Secara definisi yang sebenarnya, gasifikasi adalah proses konversi energi dari bahan bakar yang mengandung karbon (padat ataupun cair) menjadi gas yang disebut producer gas dimana gas tersebut memiliki nilai bakar dengan cara oksidasi parsial pada temperatur tinggi. Produk luaran gasifikasi yang telah dimurnikan adalah terdiri dari campuran karbon. monoksida (CO), hydrogen $\left(\mathrm{H}_{2}\right)$ dan metan $\left(\mathrm{CH}_{4}\right)$ yang disebut syngas dan pengotor inorganik seperti NH3, HCN, H2S, debu halus serta pengotor organik yaitu kandungan tar. Komposisi gas ini sangat tergantung pada komposisi unsur dalam biomassa baik bentuk, ukuran partikel biomassa, serta kondisi-kondisi proses gasifikasi.

Secara umum terdapat 4 proses gasifikasi yaitu pengeringan, pirolisis, pembakaran dan reduksi.

a. Drying atau pengeringan proses drying dilakukan bertujuan agar mengurangi kadar air (moisture content) yang terkandung di dalam biomassa dan semaksimal mungkin kandungan air tersebut hilang. Pada proses drying temperatur berkisar antara $100-300^{\circ} \mathrm{C}$.

b. Pirolisis terjadi ketika biomassa mulai mengalami kenaikan temperatur kisaran suhu antara $250-700^{\circ} \mathrm{C}$. Pada tahap ini volatile yang terdapat pada biomassa terlepas dan menghasilkan arang. Tahap pirolisis merupakan reaksi endothermic yang panasnya diperoleh dari oksidasi. Hasil pirolis ada tiga jenis yaitu $\left(\mathrm{H}_{2}\right.$, $\mathrm{CO}, \mathrm{CO}_{2}, \mathrm{H}_{2} \mathrm{O}$, dan $\mathrm{CH}_{4}$ ), tar, dan arang.

b. Oksidasi atau proses pembakaran.

Oksidasi atau pembakaran merupakan reaksi yang penting terjadi di dalam reaktor akan mengalami proses oksidasi parsial, dimana proses ini merupakan proses eksoterm yang melepas sejumlah panas pada interval suhu diatas $900^{\circ} \mathrm{C}$.

C. Proses reduksi. Proses reduksi merupakan tahapan gasifikasi yang melibatkan suatu rangkaian endothermic. Proses reduksi gas $\mathrm{CO}_{2}$ dan $\mathrm{H}_{2} \mathrm{O}$ ini terjadi pada interval suhu 400$900^{\circ} \mathrm{C}$. Reduksi gas $\mathrm{CO}_{2}$ melalui reaksi kesetimbangan boudouard equilibrium reaction dan reduksi gas $\mathrm{H}_{2} \mathrm{O}$ melalui reaksi kesetimbangan water gas reaction, dimana reaks i reaksi tersebut secara dominan dipengaruhi ole h suhu dan tekanan.

\subsection{Prinsip Kerja Sistem Dual Fuel}

Sistem Diesel Dual Fuel (DDF) adalah mesin diesel standar yang ditambahkan bahan bakar lain pada intake monifold dengan udara di dalam silinder mesin, baik diijeksikan secara langsung maupun menggunakan mixer dengan penyalaan bahan bakar solar yang disebut pilot fuel. Bahan bakar ganda yang dapat digunakan seperti solarsyngas memiliki kelebihan seperti menghemat konsumsi dan biaya penggunaan solar sebagai bahan bakar. Biaya modifikasi mesin relatif lebih murah dibanding mengkonversi mesin gas (gas engine). Lebih jauh lagi aplikasi syngas dengan sistem dual fuel pada mesin diesel sangat ekonomis karena bahan baku bersumber dari biomasa, ramah lingkungan dan dapat meningkatka $\mathrm{n}$ efisiensi mesin, Azomiv et al.,2011.

\subsection{Pengaturan Parameter Gasifikasi}

Parameter penting operasi gasifikasi seperti ekivalen rasio (ER), Air Fuel Ratio (AFR) aktual mengunakan pola pengaturan operasi gasifier yang dilakukan pada penelitian sebelumnya Djafar dan Darise 2018 yaitu kecepatan udara $15 \mathrm{~m} / \mathrm{s}$ pada AFR 1.8 dan ER 0.25 serta laju komsumsi bahan bakar $1.7 \mathrm{~kg} / \mathrm{Jam}$. Parameter-parameter tersebut sangat penting dilakukan untuk menjamin gas mampu bakar yang dihasilkan gasifier benar-benar berkualitas dan tidak merusak komponen-komponen penting pada mesin diesel.

\subsection{Evaluasi Gasifikasi Tongkol Jangung}

Proses gasifikasi tongkol jagung dilakukan pada reaktor downdraft yang kondisi adiabatik. Adapun hasil pengujian nilai kalor lower heating value (LHV) tongkol jagung sebesar $10.85 \mathrm{MJ} / \mathrm{kg}$ (Rizkal Sudarmanta 2016). Sedangkan higher 
heating value (HHV) menggambarkan kapasitas energi maksimum yang diperoleh melalui proses pembakaran (persamaan 1). Untuk menghitung efisiensi gasifikasi biomassa dapat ditentukan dari perbandingan energi yang terkandung dari syngas dengan energi yang terkandung dalam biomassa persamaan 2 .

$$
\begin{gathered}
\mathrm{LHV}=\mathrm{HHV}-(\mathrm{C}) \cdot[\mathrm{W}+(0.09 \mathrm{H}) \cdot(1-\mathrm{W}) \\
\eta_{G}=\frac{L H V g \cdot\left(\bar{Q}_{G}\right)}{L H V_{M} \cdot(\dot{W} m)} \%
\end{gathered}
$$

Secara umum lower heating value gas $(\mathrm{LHVg})$ dari reaktor dawn draft berkisar 4-6 MJ.N.m ${ }^{3}$ (Martínez et al.,2012) maka untuk menentukan efisiensi gas dingin gasifikasi $\left(\eta_{G}\right)$ pada penelitian ini adalah $4.5 \mathrm{MJ}^{-\mathrm{Nm}^{-3}}$. Hal ini relevan dengan penelitian Martinez et al., dan Galindo et al.,2014 yang berkaitan dengan downdraft dua laluan udara. Sedangkan flow rate ( $\left.\bar{Q}_{G}\right)$ syngas sebesar $14.3 \mathrm{~N} \cdot \mathrm{m}^{3} \mathrm{~h}^{-1}$ chaves et al.,2016 yang nilainya relevan dengan penelitian yang dilakukan Boloy et al.,2011.

\subsection{Analisis Mesin Diesel Generator Set}

Dalam pengujian mesin diesel menggunakan bahan bakar sistem dual fuel, putaran mesin juga dijaga konstan pada 1500 rpm kemudian dilakukan variasi pembebanan listrik pada interval 200watt. Analisis yang berkaitan dengan mesin generator set maka konsumsi bahan bakar spesifik (SFC) yaitu jumlah bahan bakar persatuan waktu (kg/jam) berbanding dengan daya yang dihasilkan $(\mathrm{kW})$ dalam persamaan 3 .

$$
S F C=M_{f} / N_{e}
$$

$$
\begin{array}{ll}
\mathrm{M}_{\mathrm{f}} & =\text { Konsumsi bahan bakar }(\mathrm{kg} / \mathrm{jam}) \\
\mathrm{Ne} & =\text { Daya yang dihasilkan }(\mathrm{kW}) \\
\mathrm{SFC} & =\text { spesific fuel consumption }(\mathrm{kg} / \mathrm{jam} . \mathrm{kW})
\end{array}
$$

Performa gasifier engine system adalah diukur dari rasio energi listrik yang dibangkitkan dengan energi input yang dihasilkan dari mesin diesel dan bahan bakar biomassa yang disebut total efisiensi sistem Galindo et al., 2014 yang ditunjukkan pada persamaan 4 sebegai berikut.

$$
\eta o=P e /\left(m d . H d+B_{F R} x H H V b / 3.6\right) \times 100 \%
$$

$\mathrm{Pe} \quad=$ Daya yang dihasilkan $(\mathrm{kW})$

$\mathrm{Vpg}=$ Flowrate gas $(\mathrm{m} 3 / \mathrm{jam})$

$\begin{array}{ll}\mathrm{Bfr} & =\text { Biomassa Feed rate }(\mathrm{kilogram} / \mathrm{jam}) \\ \mathrm{Hd} & =\text { Heating value }(44.8 \mathrm{MJ} / \mathrm{kg}) \\ \mathrm{Md} & =\text { Diesel Fuel Comsuption }(\mathrm{mm} / \mathrm{second}) \\ \mathrm{LHVb} & =\text { Heating value biomassa }(\mathrm{Mj} / \mathrm{kg}) \\ \mathrm{LHVg} & =\text { Low heating value gas }\left(\mathrm{MJ} / \mathrm{m}^{3}\right)\end{array}$

\section{Pembahasan Hasil Penelitian}

Untuk mendapatkan tujuan penelitian maka dilakukan dua tahapan percobaan pengujian sebagai berikut.

a. Pengujian reaktor gasifikasi

Sebelum dilakukan integrasi syngas ke sistem dual fuel mesin diesel generator maka terlebih dahulu setup gasifier yaitu menggunakan bahan baku tongkol jagung sebanyak $5 \mathrm{~kg}$, ekivalen rasio (ER) 0.25 dengan kecepatan udara $10 \mathrm{~m} / \mathrm{s}$ untuk sekali pengujian (batch). Produser gas berupa $\mathrm{CO}, \mathrm{CH}_{4}$, $\mathrm{H}_{2}$ dan $\mathrm{CO}_{2}$ dapat ditunjukkan pada Tabel 1 sebagai berikut.

Tabel 1 Komposisi Gas Hasil Penelitian

\begin{tabular}{|l|c|c|c|c|c|c|}
\hline $\begin{array}{l}\text { Komposisi } \\
\begin{array}{c}\text { Gas rata- } \\
\text { rata (\%) }\end{array}\end{array}$ & $\mathrm{H}_{2}$ & $\mathrm{O}_{2}$ & $\mathrm{CH}_{4}$ & $\mathrm{CO}$ & $\mathrm{CO}_{2}$ & $\mathrm{~N}_{2}$ \\
\cline { 2 - 7 } & 7.9 & 10.3 & 13.2 & 11.03 & 14.1 & 43.3 \\
\hline \multicolumn{2}{|l|}{ Ekivalen Rasio } & 0.25 & \\
\hline $\begin{array}{l}\text { Laju Aliran } \\
\text { Udara }\end{array}$ & $10 \mathrm{~m} / \mathrm{s}$ \\
\hline
\end{tabular}

Komposisi produser gas yang terdapat pada Tabel 1 merupakan persentase $(\%)$ rata-rata selama satu jam pengujian yang terbaca pada gas analizer secara real time. Berdasarkan hasil pengujian maka gas analizer dapat mengukur $\mathrm{H}_{2}, \mathrm{O}_{2}, \mathrm{CH}_{4}, \mathrm{CO}$, dan $\mathrm{CO}_{2}$ $\%$ by volume. Sedangkan nitrogen $\left(\mathrm{N}_{2}\right)$ ditentukan dari pengurangan semua komponen-komponen dari $100 \%$ dengan asumsi terdapatnya gas-gas lain diabaikan. Selama proses pengujian syngas pada sistem dual fuel diperoleh beberapa kondisi persentase komposisi gas yang fluktuatif dengan interval yang cukup signifikan misalnya berturutturut kosentrasi $\mathrm{O}_{2}(10,2-26,7 \%), \mathrm{H}_{2}(7,9-13,6 \%)$, $\mathrm{CH}_{4}(6,6-19,5 \%)$, $\mathrm{CO}(9,2-16,5 \%)$,dan kosentrasi $\mathrm{CO}_{2}$ (6,3-14,5\%). Hasil ini berkorelasi dengan literatur Jena et al.,2018 yaitu ketika gasifier beroperasi pada ER 0.2-0.4 dihasilkan interval suhu reaktor antara $650-900^{\circ} \mathrm{C}$. Sedangkan persentase kosentrasi dari syngas yang dihasilkan memiliki nilai yang variatif yaitu disaat persentase $\mathrm{CH}_{4}, \mathrm{CO}$ dan $\mathrm{CO}_{2}$ meningkat maka nilai $\mathrm{O}_{2}$ dan $\mathrm{H}_{2}$ mengalami penurunan. Hal lain yang dapat diamati bahwa ketika suhu reaktor semakin meningkat yaitu sekitar $900^{\circ} \mathrm{C}$ maka tren $\mathrm{H}_{2}$ relatif konstan tetapi Produksi $\mathrm{CH}_{4}$ dan $\mathrm{CO}_{2}$ semakin kecil akibat reaksi endothermic semakin dominan terjadi di dalam rekator. 


\subsection{Efisiensi Gasifikasi downdraft Double Stage. \\ Efisiensi termal gasifikasi biomassa sering} diukur sebagai efisiensi gas dingin $\left(\dot{\eta}_{\text {cold gas }}\right.$ efficiency). Dalam efisiensi gas dingin produk dari LHV gas dan laju volumetrik gas yang dihasilkan dianggap sebagai output termal gasifier. Dengan mengetahui nilai kalor bawah tongkol jagung maka nilai kalor atas (HHV) dapat ditentukan sebesar 12.5 $\mathrm{Mj} / \mathrm{kg}$ (Persamaan 1). Sedangkan hasil perhitungan didapatkan efisiensi gas dingin dari reaktor downdraft adalah sebesar $35.5 \%$ (persamaan 2).

\subsection{Proses Pengujian Mesin Diesel Sistem Single Fuel}

Pengujian mesin diesel sistem sistem single fuel atau kondisi standar yaitu menggunakan bahan bakar solar. Pada penelitian digunakan 1 liter bahan bakar solar dimana putaran mesin dijaga konstan pada $1500 \mathrm{rpm}$ kemudian dilakukan variasi tanpa pembebanan dan menggunakan pembebanan antara 200-2000 watt pada interval 200 watt. Hal ini bertujuan adalah untuk melihat seberapa besar bahan bakar yang dikonsumsi mesin diesel dalam setiap menitnya dan akan dicatat setiap penambahan beban listrik. Hasil ini akan digunakan sebagai pembanding pada sistem dual fuel.

Tabel 2. Hasil Pengujian Mesin Diesel Single Fuel

\begin{tabular}{|c|c|c|c|c|c|c|c|c|c|c|c|c|c|c|}
\hline \multirow{2}{*}{ Konstan } & \multirow{2}{*}{ Sistem } & \multicolumn{9}{|c|}{ Variasa pembebanan } & \multicolumn{2}{c|}{ Satuan } & Waktu \\
& & 0 & 200 & 400 & 600 & 800 & 1000 & 1200 & 1400 & 1600 & 1800 & 2000 & $\begin{array}{c}\text { Watt } \\
(\mathrm{W})\end{array}$ & (Detik) \\
\hline $\begin{array}{c}1500 \\
\text { Rpm }\end{array}$ & $\begin{array}{c}\text { Single } \\
\text { Fuel }\end{array}$ & 3.5 & 4 & 4 & 4.6 & 4.75 & 4.85 & 5 & 5.35 & 5.5 & 5.87 & 6.75 & $\begin{array}{c}\text { Milli } \\
\text { Liter } \\
\text { (ml) }\end{array}$ & 60 \\
\hline
\end{tabular}

Tabel 2 menunjukkan variasi pembebanan listrik pada interval 200 watt untuk kecepatan putar mesin $1500 \mathrm{rpm}$ dengan interval waktu 1 menit setiap variasi pengujian. Adapun rata-rata konsumsi bahan bakar yang dibutuhkan mesin diesel setelah dilakukan pembebanan adalah sebesar 4.85 $\mathrm{ml} /$ menit. Sedangkan tanpa pembebanan sebesar 3.5 $\mathrm{ml} / \mathrm{menit}$ atau kenaikan konsumsi bahan bakar sebesar $27.8 \%$ setelah terjadi pembebanan.

\subsection{Proses Pengujian Mesin Diesel Sistem Dual Fuel \\ Pada proses ini merupakan aplikasi syngas} untuk menggerakkan generator set menghasilkan energi listrik. Proses variasi sama dengan sistem single fuel. Adapun hasil data penelitian ditunjukkan pada Tabel 3 Sebagai berikut.

\begin{tabular}{|c|c|c|c|c|c|c|c|c|c|c|c|c|c|c|}
\hline \multirow[b]{2}{*}{ Konstan } & & \multicolumn{11}{|c|}{ Variasa pembebanan } & \multirow{2}{*}{\begin{tabular}{|l|} 
Satuan \\
Watt (W) \\
\end{tabular}} & \multirow{2}{*}{$\begin{array}{l}\text { Waktu } \\
\text { (Detik) }\end{array}$} \\
\hline & & 0 & 200 & 400 & 600 & 800 & 1000 & 1200 & 1400 & \begin{tabular}{|l|l}
1600 \\
\end{tabular} & 1800 & 2000 & & \\
\hline \multirow{2}{*}{$\begin{array}{l}1500 \\
\mathrm{Rpm}\end{array}$} & \begin{tabular}{|c} 
Single \\
Fuel
\end{tabular} & 3.5 & 4 & 4 & 4.6 & 4.75 & 4.85 & 5 & 5.35 & 5.5 & 5.87 & 6.75 & \multirow{2}{*}{$\begin{array}{c}\text { Milli } \\
\text { Liter } \\
(\mathrm{ml})\end{array}$} & \multirow{2}{*}{60} \\
\hline & \begin{tabular}{|l|} 
Dual \\
Fuel
\end{tabular} & 2 & 1 & 1.25 & 1.37 & 1.5 & 2.37 & 2.5 & 2.87 & 3 & 3.12 & 40 & & \\
\hline
\end{tabular}

Data pengujian yang terdapat pada Tabel 3 menunjukkan jumlah konsumsi bahan bakar hasil pengujian, dimana rata-rata konsumsi bahan bakar adalah $2.29 \mathrm{ml} / \mathrm{menit}$

\subsection{Analisis Performa Mesin Diesel Generator}

Beberapa performa mesin diesel yang akan dianalisis pada penelitian ini adalah sebagai berikut. a. Perbandingan Konsumsi Bahan Bakar Single Fuel dan Dual Fuel.

Perbandingan konsumsi bahan bakar untuk melihat seberapa besar jumlah bahan bakar yang tersubstitusi dengan adanya penambahan bahan bakar barupa syngas untuk menggerakkan energi listrik. Hasil perbandingan dapat ditunjukkan pada Gambar 2 sebagai berikut.

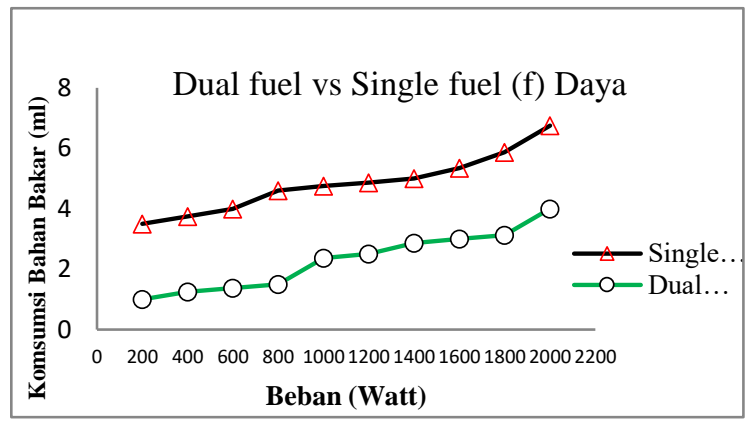

Gambar 2. Perbandingan single fuel dengan dual fuel

Berdasarkan hasil pengujian diketahui pengaruh syngas terhadap konsumsi bahan bakar mesin diesel. Adapun single fuel dengan adanya penambahan beban listrik maka jumlah konsumsi bahan bakar juga semakin bertambah. Dimana pada pembebanan 200 watt diperlukan $3.5 \mathrm{ml}$ solar sedangkan pada pembebanan maksimal yaitu 2000 Watt dibutuhkan $6.75 \mathrm{ml}$ solar. Sedangkan sistem dual fuel jumlah konsumsi bahan bakar pada pembebanan 200 watt diperlukan solar sebesar $1 \mathrm{ml}$. Sementara pada beban tertinggi yaitu 2000 watt dibutuhkan solar $4 \mathrm{ml} / \mathrm{menit}$. Hasil grafik pada Gambar 1 sudah bersesuaian dengan penelitian yang dilakukan Rizkal dan Sudarmanta, (2016) dimana didapatkan nilai laju energi pada pengoperasian dual fuel lebih tinggi dibandingkan pengoperasian single fuel. Hal ini disebabkan untuk setiap siklus pada setiap daya yang sama maka adanya penambahan gas menyebabkan proses pencampuran bahan bakar menjadi lebih baik, sehingga untuk setiap siklus yang sama kebutuhan energi yang digunakan untuk proses pembakaran menjadi lebih baik untuk pembebanan yang sama pada setiap 
siklusnya. Adapun persentase bahan bakar yang tersubstitusi adalah $47.4 \%$ dari kondisi standar.

b. Analisis Mesin Diesel Generator Set; Konsumsi bahan bakar spesifik (SFC)

Pada umumnya sistem gasifikasi yang produser gasnya yang diintegrasi dengan mesin sistem pembakaran dalam memiliki flow rate syngas $14.3 \mathrm{~N} \mathrm{~m}^{3} \mathrm{~h}^{-1}$. Sedangkan konsumsi bahan bakar spesifik pada penelitian ini didapatkan nilai sebesar 1.22 kg/jam.kW (Persamaan 2). Umumnya SFC dipengaruhi energi potensial dan campuran produser gas sebagai fungsi beban generator yang diberikan.

b. Efisiensi Total Sistem Mesin Generator Set

Performa mesin generator umumnya dipen garuhi oleh efisiensi termal mesin. Untuk konversi daya mekanik menjadi daya listrik yang dikopel dengan generator efisiensi tertinggi sebesar 95\%. Saat adanya peningkatan konsumsi bahan bakar spesifik maka efisiensi generator set mengalami penurunan. Berdasarkan hasil analisis yang telah dilakukan maka efisiensi total sistem pada penelitian ini adalah sebesar $10.8 \%$ (persamaan 4). Hasil ini berkorelasi dengan penelitian Boloy et al.,2011yang menghasilkan efisiensi downdraft yang dikopel dengan mesin generator sebesar $12.8-13.5 \%$ pada beban maksimum.

\section{Kesimpulan Dan Saran}

Berdasarkan hasil pengujian yang telah dilakukan dapat ditarik kesimpulan dan saran sebagai berikut:

a. Kesimpulan

1. Komponen syngas yang dihasilkan masing-masing komponen berupa $\mathrm{O}_{2}$ $(10,2-26,7 \%), \mathrm{H}_{2}(7,9-13,6 \%), \mathrm{CH}_{4}(6,6-$ $19,5 \%), \mathrm{CO}(9,2-16,5 \%)$, kosentrasi $\mathrm{CO}_{2}$ $(6,3-14,5 \%)$.dan $\mathrm{N}_{2}(59.8-43.3 \%)$

2. Efisiensi gas dingin gasifikasi diperoleh sebesar $35.5 \%$ dengan konsumsi bahan bakar sebesar $1.22 \mathrm{~kg} / \mathrm{jam} . \mathrm{kW}$.

3. Konsumsi bahan bakar mode single fuel pada beban minimal sebesar $3.5 \mathrm{ml} /$ menit dan pembebanan maksimal sebesar 6.75 $\mathrm{ml} / \mathrm{menit}$. Sedangkan sistem dual fuel pada beban minimal sebesar $1 \mathrm{ml} /$ menit dan pada beban maksimal sebesar 4 $\mathrm{ml} /$ menit. Dengan persentase bahan bakar solar yang tersubtitusi sebesar $47.4 \%$.

4. Efisiensi total sistem sebesar $10.8 \%$

\section{b. Saran}

Untuk penelitian selanjutnya perlu dilakukan optimasi efisiensi reaktor gasifikasi downdraft.

\section{Daftar Pustaka}

Raman, N.K. Ram*, Gupta. Energy 54 (2013) A dual fired downdraft gasifier system to produce cleaner gas for power generation: Design, development and performance analysis. Elsevier. Energy 170

Jena $^{1 *}$, M Shyam ${ }^{2}$ and Joshi ${ }^{3}$.. Tar and Particulate Matters Removal from Producer Gas by using Oily Organic Filter Media. Environmental Science.11(1) 33-44

Rizkal Sudarmanta (2016). Karakterisasi Unjuk Kerja Diesel Engine Generator Set Sistem Dual Fuel Solar-Syngas Hasil Gasifikasi Briket Municipal Solid Waste (MSW) Secara Langsung. JURNAL TEKNIK 2337-3539.

Homdoung ${ }^{1}$, Tippayawong $1, *$ and Dussadee ${ }^{2}$. (2015) Performance investigation of a modified small engine fueled with producer gas. Maejo Int. J. Sci. Technol.

Nhuchhen \& Salam (2012) Experimental study on two-stage air supply downdraft gasifier and dual fuel engine system. Biomass Conv. Bioref 2:159-168

Chaves $^{\mathrm{a}}$, M.J Silva ${ }^{\mathrm{b}}$, S.M.N de Souza ${ }^{\mathrm{c}}$ D Secco ${ }^{\mathrm{c}}$, H.A Rosac, n, C.E.C and Nogueira ${ }^{c}$ E.P Frigo $b{ }^{d}$ (2016). Small-scale power generation analysis: Downdraft gasifier coupled to engine generator set. Renewable and Sustainable Energy Reviews 58 - 491498.

Djafar dan Darise. (2018). Pengaruh jumlah aliran udara terhadap nyala api efektif dari reaktor gasifikasi biomassa tipe fixed bed downdraft menggunakan bahan bakar tongkol jagung. JTech 6(2), $94-100$.

Azimov*, E.Tomita ${ }^{1}$, Kawahara ${ }^{2}$, Yuji Harada ${ }^{3}$. (2011) Effect of syngas composition on combustion and exhaust emission characteristics in a pilot-ignited dual-fuel engin operated in PREMIER combustion mode. International Journal

Martínez a,b, J.D Mahkamov c, ${ }^{*}$, Rubenildo V. Andrade b , E.E.S Lora b (2012). Syngas production in downdraft biomass gasifiers and its application using internal combustion engines. Renewable Energy 38 1-9-

Galindo AL, Lora ES, Andrade RV, Giraldo SY, Jaén RL, Cobas VM (2014). Biomass gasification in a downdraft gasifier with a two-stage air supply: effect of operating conditions on gas quality. Biomass Bioenergy;61:236-44

Boloy RAM, JL Silveira, Tuna CE, C.R and JS Antunes. (2011) Ecological impacts from syngas burning in internal combustion 
engine: technical and economic aspects.

Renew Sustain Energy; 15:5194-201.

Roy P.C a, A. Datta b, and Chakraborty (2013) An assessment of different biomass feedstocks in a downdraft gasifier for engine application. Fuel 106-864-868. 